\title{
Savage River Mine — Rock Dump Evolution
}

\author{
D.M. Brett GHD Pty Ltd, Australia
}

B.J. Hutchison Australian Bulk Minerals Pty Ltd, Australia

S. Kent Caloundra Environmental, Australia

\begin{abstract}
Operations at the Savage River mine on the west coast of Tasmania commenced in 1966 with magnetite ore being mined in a series of open pits. The steep hillside terrain and temperate rainforest environment made waste rock dumping difficult with poor practice leading to the oxidation of pyritic rock wastes in the older hillside dumps with the development of acid rock drainage (ARD).

Historically, waste rock was either being placed on steep hillside dumps or on ridges above steep sided valleys. The hillside dumps were prone to slope failures, which lead to blocked and/or polluted creeks, and the ridge top dumps were becoming uneconomic due to the long steep climbs.

The key to development of the mine was construction of a "flow-through" dump in Broderick Creek, adjacent to and a short haul from the main North Pit. This significantly increased the practicality of dump construction and allowed practical cellular construction with encapsulation of potentially acid forming (PAF) rocks.
\end{abstract}

The other problem with high dumps on steep hillsides in the wet climate was the placement and compaction of clay at relatively low angles required for stability. A simplified construction technique based on end tipping of silty-clay material over the sides of the PAF rocks and then armouring this with alkaline rock was adopted. Using this technique provides a thick zone of partially saturated soil sufficient to exclude oxygen. The armoured alkaline rock acts to increase saturation and to stabilise the clay. It also reduces the prospect of vegetative regrowth destroying the dump cover integrity.

The paper describes the evolution of waste rock dumps at Savage River mine and particularly focuses on monitoring of the current capping systems.

\section{Introduction}

The Savage River Iron mine is located in northwest Tasmania at an elevation of 100 to $350 \mathrm{~m}$ in rugged and mountainous terrain covered with dense rainforest, approximately $300 \mathrm{~km}$ northwest of Hobart. The climate of the area is characterised by cool temperatures and consistently high average annual rainfall of nearly $2000 \mathrm{~mm}$. Rainfall exceeds evaporation by a factor of at least $2: 1$.

To date mining operations have generated in excess of 50 million $\mathrm{m}^{3}$ of ore and 300 million $\mathrm{m}^{3}$ of waste rock. Current mining plans allow for the potential of a further 100 million $\mathrm{m}^{3}$ over the next 15 years. Figure 1 shows an aerial overview of the mine site with major features highlighted.

The Savage River iron deposit is located within a narrow linear belt of Pre-Cambrian rocks, comprising principally serpentinites, volcanics and schists with lesser dolomites, magnesites and amphibolites. The ore zone strikes north-south and dips near vertically. The main ore zone comprises massive and disseminated magnetite with a known strike length of $4 \mathrm{~km}$ and thickness of 100-150 m, continuing to depths of at least $600 \mathrm{~m}$.

The mine was initially opened in 1967, operating several open cut pits along the north-south trending orebody that crosses the Savage River. These pits have progressively been expanded and deepened with the mine recently announcing a further 15 years expansion program.

The ore is concentrated at the mine site then transported as slurry in a pipeline $85 \mathrm{~km}$ to Port Latta on the coast. This pipeline itself, which is still in service today, is a tribute to the engineering design and construction expertise that was implemented over 40 years ago. At Port Latta the concentrate is pelletised 
prior to shipping to customers within Australia and internationally who value the fluxing properties of the product.

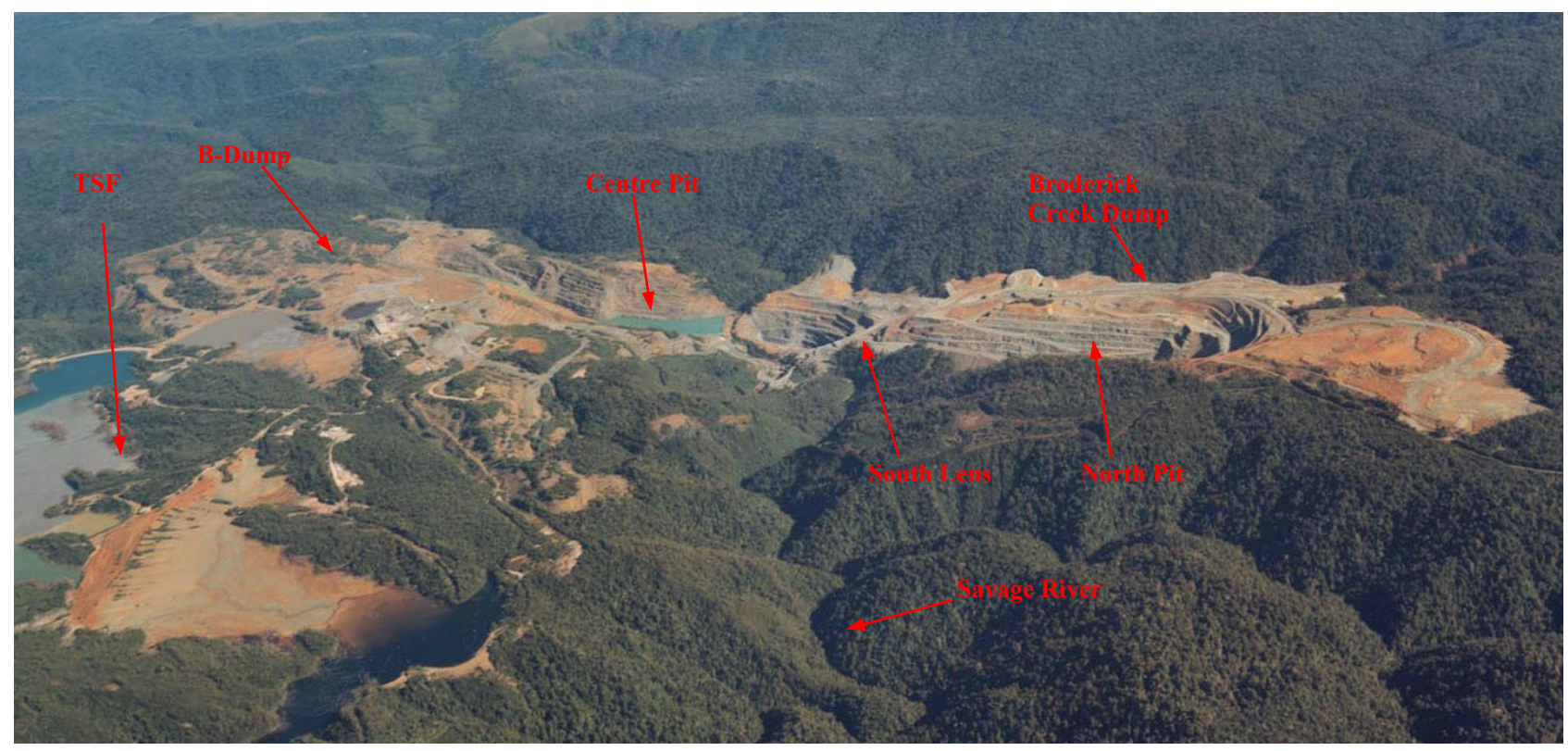

Figure 1 Aerial view - Savage River mine

Operations over the first 30 years of mine life caused environmental harm to approximately $30 \mathrm{~km}$ of the Savage River. This section was found in 1995 to have lost $90 \%$ of its invertebrate biodiversity and $99 \%$ of its invertebrate abundance. Savage River water quality reflected the influences of past mining, with suspended solids and acid rock drainage (ARD) containing elevated dissolved copper, aluminium, nickel and manganese. The ecosystem of the Savage River above the mine is also affected because the pollution prevents fish from migrating between the river and the sea, an essential part of the lifecycle of most Tasmanian native fish.

Australian Bulk Minerals (ABM) purchased the mine from the Tasmanian Government and took over operations in 1996. As part of the purchase agreement the Tasmanian Government retained liability for the historic AMD as long as ABM adopted world's best environmental practices (WBEP) in their waste disposal management. In addition ABM agreed to assist the government in remediation of the AMD through contribution to a jointly funded Savage River Remediation Project (SRRP).

\section{Historical dump performance}

During the first few years of the SRRP various studies were carried out to determine the sources of ARD and to look at feasible remediation methods. This determined that the majority of pollution was sourced from historic waste rock dumps. One of these, known as Hairpin dump became the subject of the first study of the SRRP.

Hairpin dump was one of the last areas used by the original mine operators with waste from the eastern and western walls of North Pit being dumped there between 1993 and 1994. An investigation in late May 2000 involved: drilling five holes; sampling and testing for a wide range of physical and chemical properties and the installation of oxygen and temperature measuring probes. Hydraulic properties within the dump were determined from test pits and a range of permeability and infiltration tests. Bulk density and sizing trials were carried out on a large sample.

The geochemical assessment of the dump has concluded that:

- Hairpin dump is oxidising rapidly, with almost $30 \%$ of the sulphides in the dump already oxidised after only 6 years. If oxidation continued at the measured rate, the sulphides would be exhausted in 
about 20 years. In practice, the rate of oxidation was expected to slow and oxidation to continue for significantly longer.

- The effluent from the dump carries only a small proportion of the contaminants produced with the results that the dump contained a very large store of readily leachable contaminants, which, if mobilised, could sustain present contaminant loads in the outflow for decades, even without further oxidation.

- Since oxygen access into Hairpin dump appeared to be primarily by advection, covering the dump would quite likely reduce the rate of oxidation. However, because the contents of the dump are already appreciably oxidised and a large amount of readily leachable contaminants are stored in the dump, reducing the rate of oxidation may not lead to any appreciable reduction in contaminant load exiting the dump.

- If the present effluent quality is unacceptable for discharge to the Savage River, treatment is likely to be required, regardless of whether a cover is constructed.

- To the extent that a cover does reduce the rate at which the dump contents oxidise and contaminants leach out, this potentially increases the time frame of ongoing contamination.

In summary, the capping of the historical dumps would not provide significant environmental benefit and could extend the period of environmental harm. However it was shown that capping does have the potential to have a significant impact on the economics of acid drainage remediation due to a major reduction in water flux and the physical infrastructure required to transport and treat seepage water. This behaviour is a very important part of the current consideration of water management and treatment options at the Savage River Mine with significant cost implications (Brett, 2006).

\section{ABM dump design and operation}

Australian Bulk Minerals had a good understanding of the ARD issue with the historic waste rock dumps and were therefore able to implement a disposal strategy to control the problem in the new dumps required for their operation. The strategy developed around three key features as follows:

- A rigorous rock classification system in the pit to assign waste classes.

- The development of "flow through dump" technology.

- The development of a practical capping process.

\subsection{Rock type classification}

The waste rock at Savage River has been identified as falling into four broad categories as follows:
A type
Alkaline (non-acid forming - NAF) or very durable igneous rock.
B type
Effectively neutral.
C type
Clay or highly weathered rock.
D type
High risk acid forming PAF.

The classification is undertaken by site geologists by inspection of drill cuttings from the blast holes in the pit prior to blasting. This classification is based on net acid generation (NAG) tests on rock types and from an assessment of the pyrite content. Following blasting, the geologists set up signage in the pit. The dumps are set up with similarly signed dump areas for strategic dumping of the various rock types. Training of operators in ARD issues has been very successful in ensuring compliance with the dump operations plan. The primary focus of the planning is to use "A type" for flow-through dump construction or armouring/alkaline cover for the clay capping and encapsulation of the "D type" PAF rock with type C. The proposed dump arrangement is shown in Figure 2. 


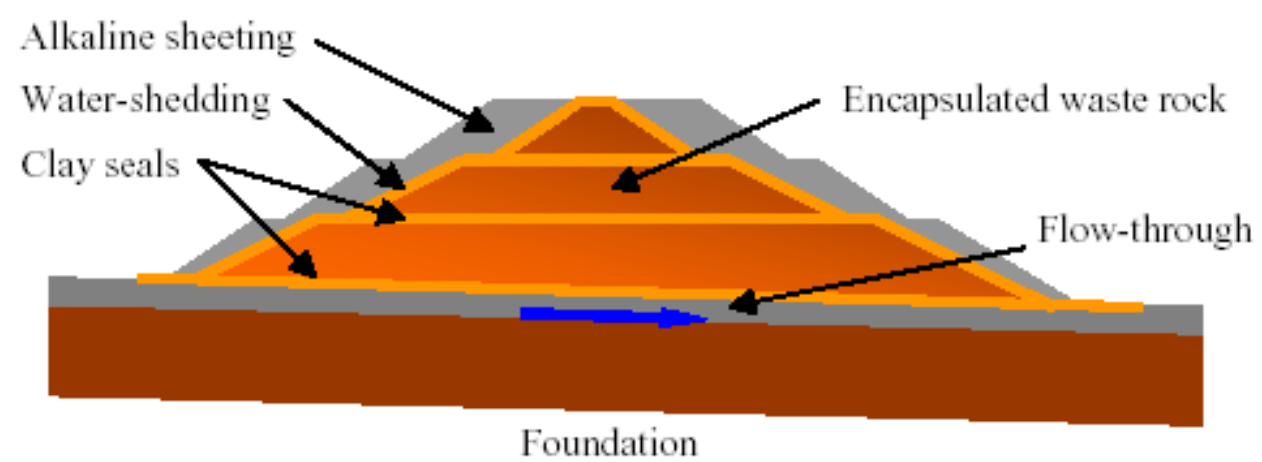

Figure 2 Schematic of proposed waste rock dump arrangement

\subsection{Flow through dump technology}

Due to the extremely rugged topography of the Savage River area, the siting of waste rock dumps is difficult and the current main waste rock dump, Broderick Creek dump, has been developed in a valley adjacent to the northern pit of the mine. A flow-through rockfill dam was used in the later stages of mining by previous operators to resolve erosion in Broderick Creek. This type of structure requires a free draining construction material with permeability consistent with the required flow capacity. Typically this has comprised rockfill, grading from 200 to $500 \mathrm{~mm}$ sized rock.

The original flow-through concept has been extended (Brett et al., 2003) to allow the development of an extended flow-through zone under expanded dumps, which now span the complete breadth of Broderick Creek as shown in Figure 3. As this will cater for the majority of planned waste rock disposal, it has effectively made the mine viable.

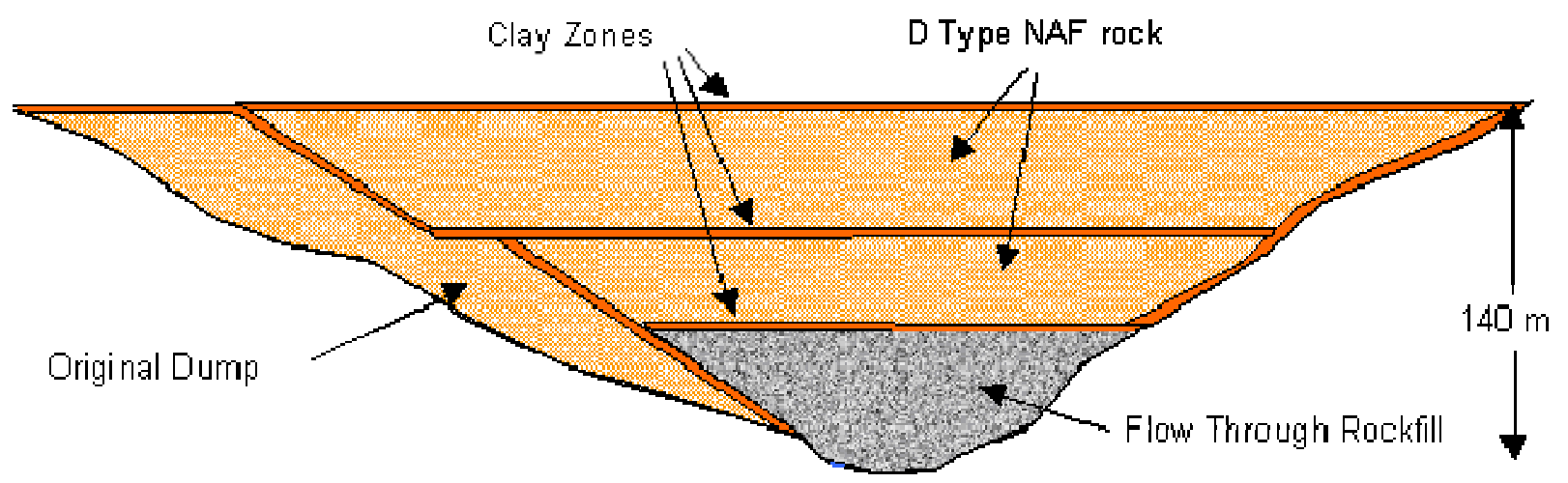

\section{Figure 3 Cross section of Broderick creek dump}

The various rock types can be allocated into the dump zones, which allows encapsulation of acid forming materials and a flow-through zone in the creek bed.

Staged construction of the dump has taken into account the sources of rock available at any time, the need to maintain dump stability and the need to place hard, stable rock into flow-through zones. Dump planning and operations need to be adequately flexible in order to allow strategic placement of available materials on a day-to-day basis. This has required commitment from management and attention to the training of operators. Waste placement plans are updated daily by mine geologists in accordance with predictions of the volumes of various classifications of waste to be moved. Figure 4 shows a view of the operating dump.

$\mathrm{ABM}$ have maintained monitoring records of head loss and rainfall over the past few years, which has shown an average hydraulic gradient of $1.1 \%$ and a characteristic permeability of $0.26 \mathrm{~m} / \mathrm{sec}$, given an effective area of $350 \mathrm{~m}^{2}$ for the flow-through zone. 


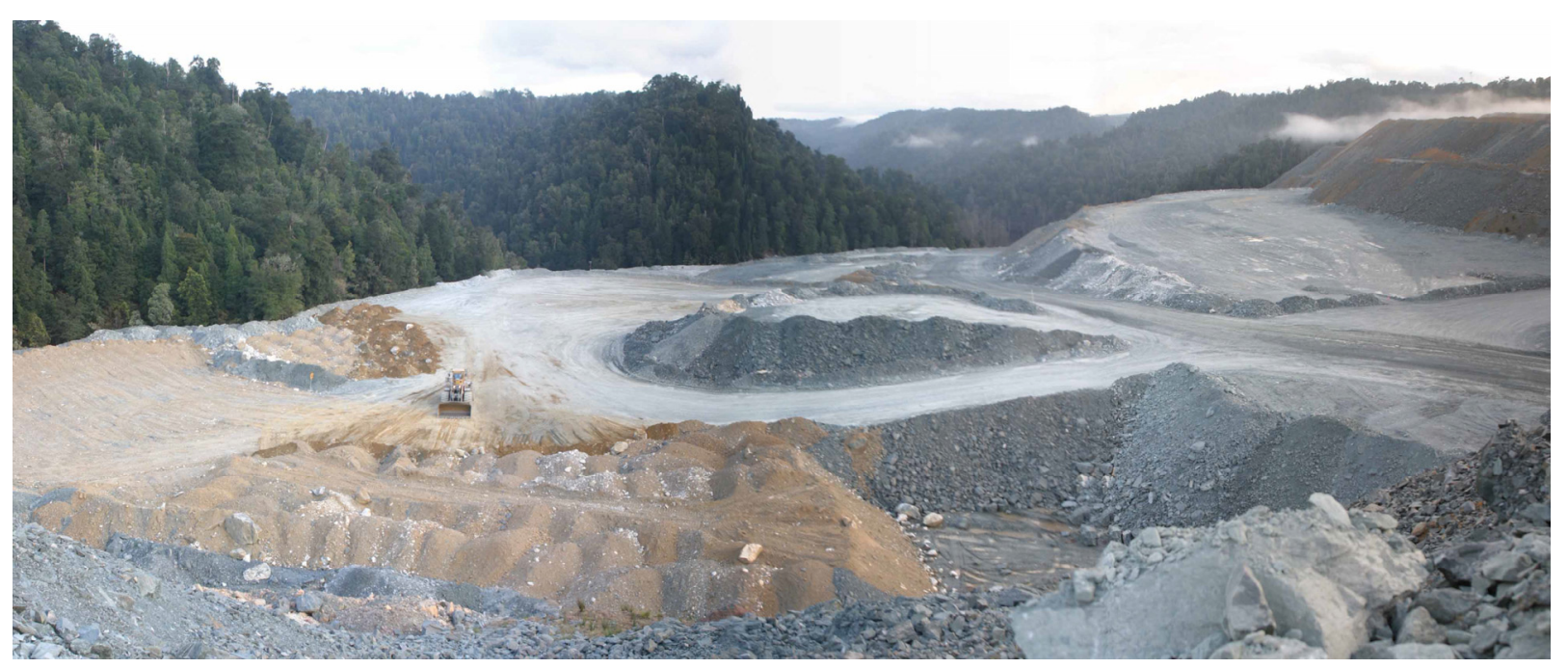

Figure 4 Broderick Creek dump - rising $140 \mathrm{~m}$ above creek level

\subsection{Development of clay capping systems}

ABM have two issues for capping systems at different areas of the mine. The first involves capping of the historic dumps where oxidation is already well advanced. The second involves ensuring that oxidation of PAF waste in the new dumps is prevented.

\subsubsection{Water shedding covers}

The benefits of water shedding covers for reducing the hydraulic load of contaminated seepage from historic waste rock dumps has been demonstrated (Brett, 2006). This led to a significant project under the SRRP for $\mathrm{ABM}$ to construct a water shedding cover to B-dump as part of their operational waste rock dumping. The main features specified for the cover were:

- Final cover to comprise selected silt soil or weathered rock.

- Target permeability $10^{-7}$ to $10^{-8} \mathrm{~m} / \mathrm{sec}$.

- Target density 95\% mdd (standard).

- Minimum $0.5 \mathrm{~m}$ thick.

- Cover materials $1 \mathrm{~m}$ soil or $0.5 \mathrm{~m}$ rock.

- Drains to be stabilised with rocks particularly on steep grades.

Soil from mine pit development, which would be used for the surface cover materials gave measured permeabilities of $10^{-7}$ to $10^{-10} \mathrm{~m} / \mathrm{sec}$. Soil from the permeability tests for the trial section of cap at B-dump gave permeability results of $10^{-6}$ and $10^{-8} \mathrm{~m} / \mathrm{sec}$ for roller clay and $5 \times 10^{-8} \mathrm{~m} / \mathrm{sec}$ for haul roads.

Analysis has shown that an effective cover should reduce infiltration to approximately $15 \%$ of incident rainfall.

A view of B-dump is shown in Figure 5. 


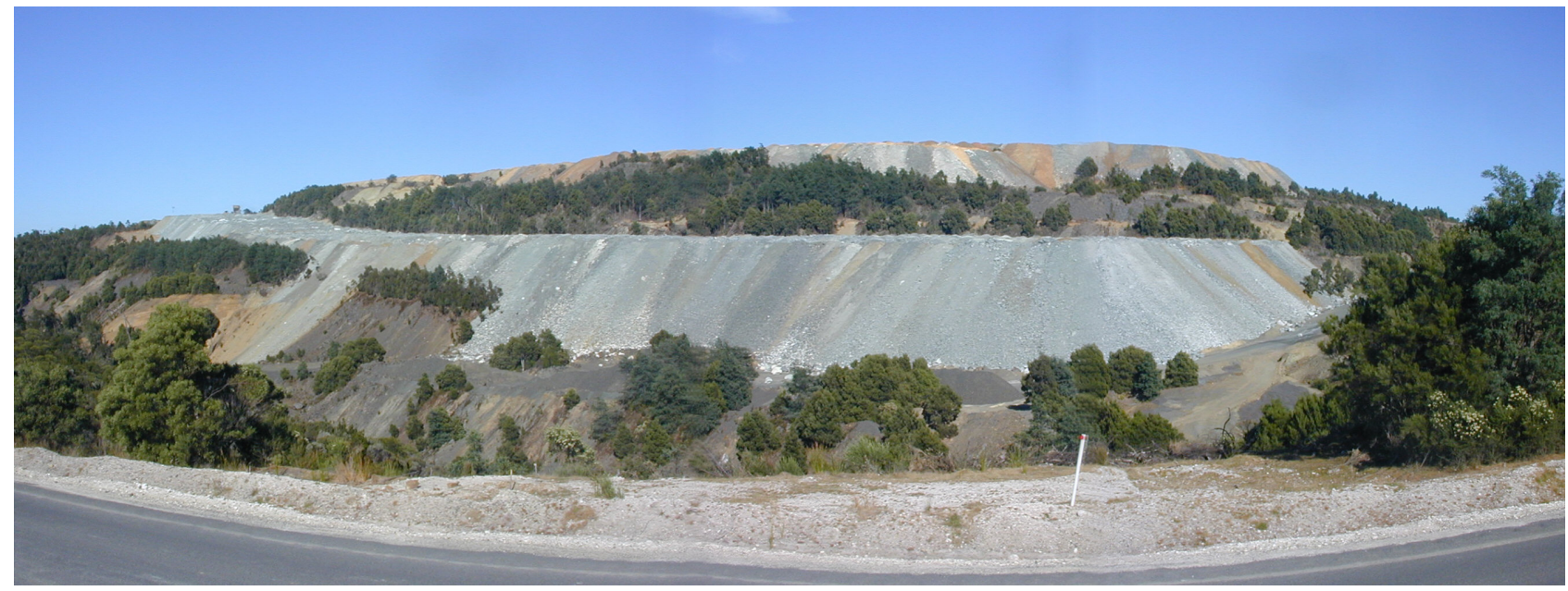

\section{Figure 5 B-dump}

As part of the construction works, V-notch weirs were installed with real time monitoring to evaluate the success of the cover. Monitoring of an area of $160,000 \mathrm{~m}^{2}$ for the three months to $20^{\text {th }}$ June, 2007 showed runoff to be consistently between $60 \%$ and $80 \%$ of rainfall, averaging $63 \%$. Allowing for evaportation resulted in an estimated infiltration rate equal to $7 \%$ of incident rainfall. This is better than expected from modelling.

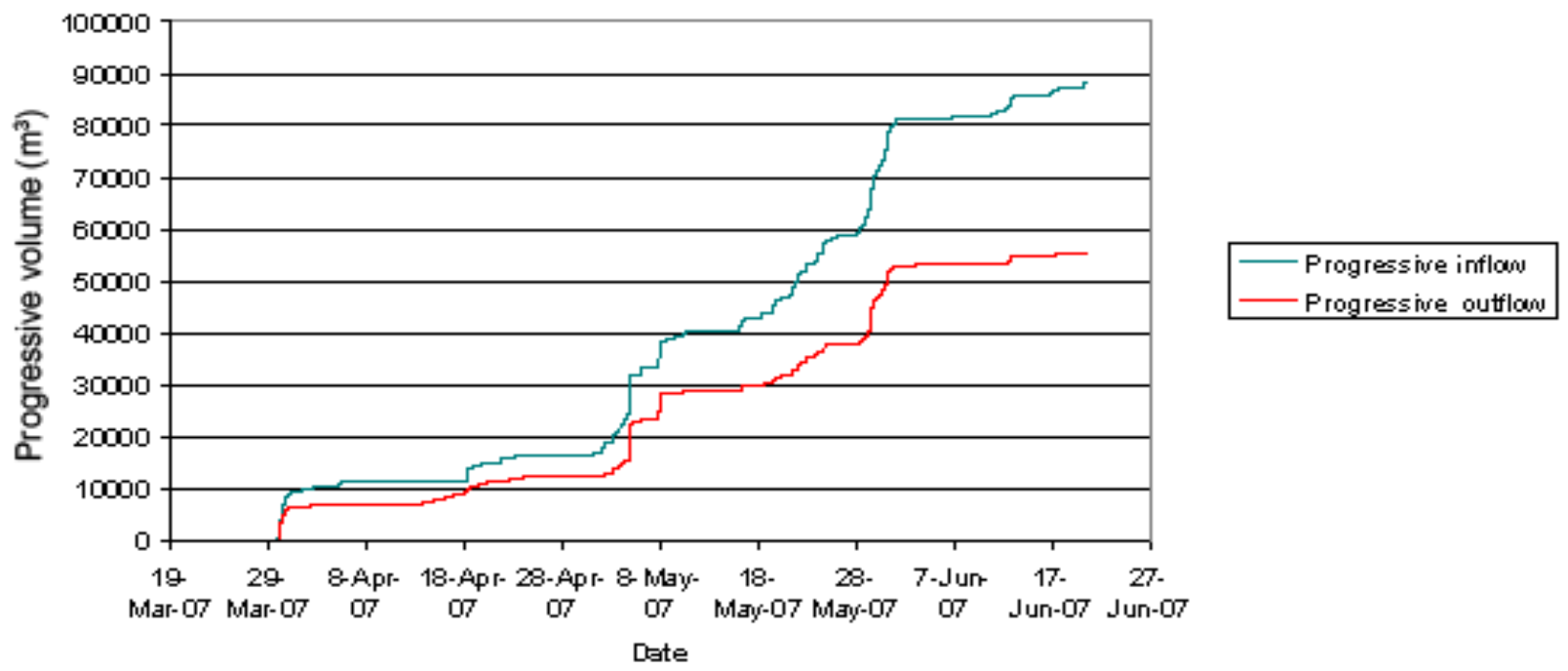

Figure 6 Inflow and outflow from B-dump water shedding cover

\subsubsection{Saturated oxygen barriers}

Early designs for clay capping allowed for flattened dump batters using a relatively thin compacted clay capping with soil overlay and revegetation. This proved problematical in practice at Savage River, with the high cost of reshaping dump faces, the difficulty in achieving compaction in the wet climate and erosion issues, leading $\mathrm{ABM}$ to develop a practical, oxygen-limiting capping system involving dumping of a weathered rock ("clay") layer over the outer face of the D-type rock and stabilising this layer with a further layer of hard NAF (A-type) rockfill. The dumped clay layer cannot be compacted but can be placed thicker than the normal thin engineered layer. The clay zone is typically 3-6 m thick. 
A key factor in the concept development was the understanding that the rate of oxygen diffusion is significantly reduced when soil cover saturations are in excess of $80 \%$ as shown in Figure 7 (Rumble, 2000). Maintaining this level of saturation has previously been shown to be feasible even with relatively permeable covers given the wet climate at Savage River. In addition, the efficiency of a cover can be improved by additional thickness of material as shown in Figure 8 (Rumble, 2000).

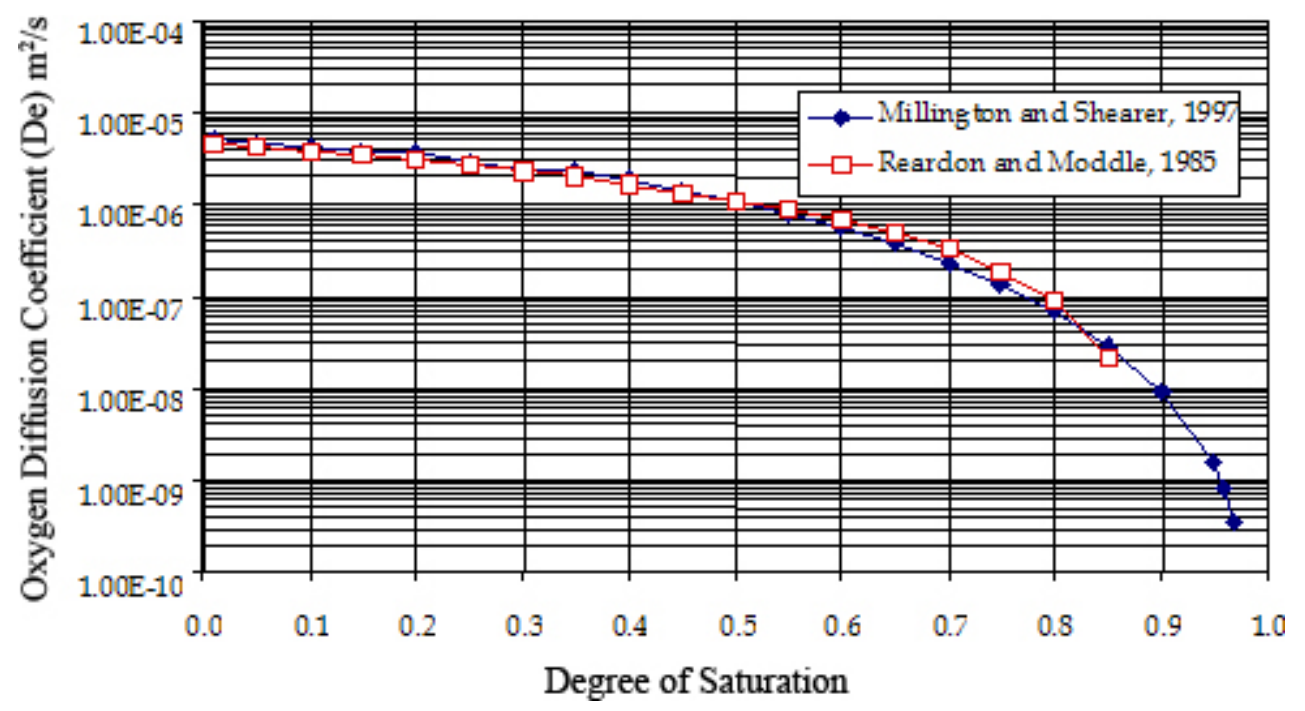

Figure 7 Diffusion coefficient as a function of degree of saturation

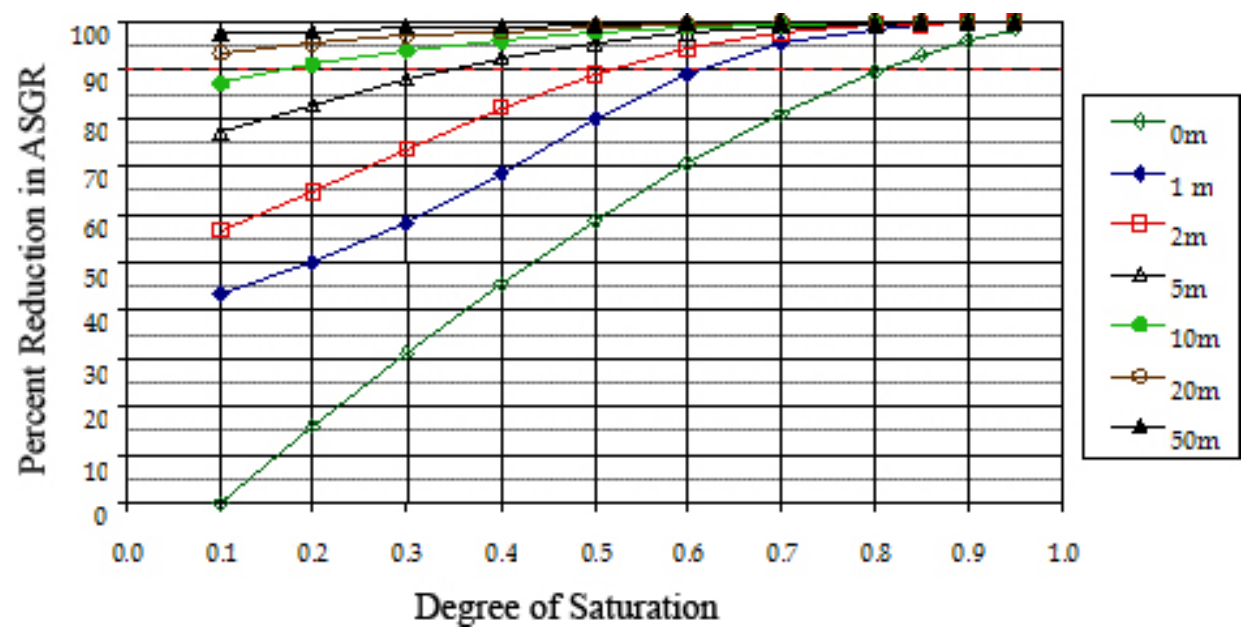

\section{Figure 8 Percent reduction in acid sulphate generation rate (ASGR) as a function of moisture and cover thickness}

Based on Figure 8 only a nominal thickness of cover would be needed to reduce ASGR by $90 \%$ based on a minimum saturation of $80 \%$. For a $2 \mathrm{~m}$ thick cover $50 \%$ saturation would be acceptable.

A $2 \mathrm{~m}$ thick cover on batter slopes has been considered the minimum practical for field placement. A typical bench height of $20 \mathrm{~m}$ was used. 
Stability modelling was undertaken using Rockscience SLIDE 2D software. The rock on top of the capping and the waste rock covered by the capping have been assumed to have the same properties as listed in Table 1.

Table 1 Soil properties

\begin{tabular}{|c|c|c|c|c|}
\hline Material & $\begin{array}{c}\text { Unsaturated } \\
\text { Unit Weight } \\
\left(\mathbf{k N} / \mathbf{m}^{3}\right)\end{array}$ & $\begin{array}{c}\text { Saturated } \\
\text { Unit Weight } \\
\left(\mathbf{k N} / \mathbf{m}^{3}\right)\end{array}$ & $\begin{array}{c}\text { Friction Angle } \\
\qquad\left({ }^{\circ}\right)\end{array}$ & $\begin{array}{c}\text { Cohesion } \\
\text { (kPa) }\end{array}$ \\
\hline Rock & 20 & 22 & 37 & 0 \\
\hline Clay Capping & 18 & 20 & 25 & 0 \\
\hline
\end{tabular}

These properties have been obtained from testing of site materials and confirmed by back analysis of a failure surface by ABM personnel. The friction angle for the rock is the angle of repose.

The clay layers have been assumed to be saturated. This has been modelled by putting the phreatic surface above the top clay layer and specifying that the rock below is not affected by the phreatic surface.

Results showed that a nominal $27 \mathrm{~m}$ width of rock armouring was needed for stability of a single lift as shown in Figure 9 or alternatively the face flattened to 2.4:1 slope as shown in Figure 10 to achieve a steady state Factor of Safety of 1.5.

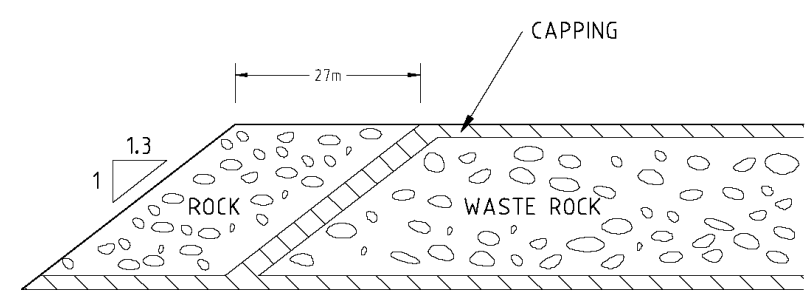

Figure 9 Type 1 - The rock berm is built at the angle of repose of the rock over the total bench height

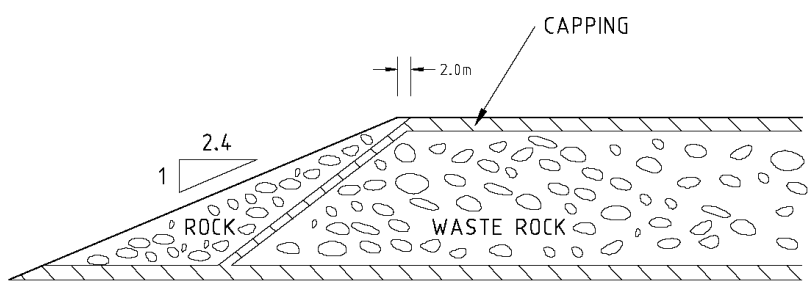

Figure 10 Type 3 - The slope of the rock berm is flattened by a bulldozer so that the rock volume used is minimised

The offset required between lifts was determined by analysing multi-lift dumps for both construction methods. The geometry was adjusted to target a factor of safety of approximately 1.5 . In each case analysed, the critical failure surface was non-circular through the clay zone. Also in each case the outer slope of the waste rock cover layer was found to be essentially independent of the offset between lifts, with the overall outer face slope for either method of construction being approximately 2.7 to 1 (horizontal to vertical). Examples of options found to be stable are shown in Figures 11 and 12. 


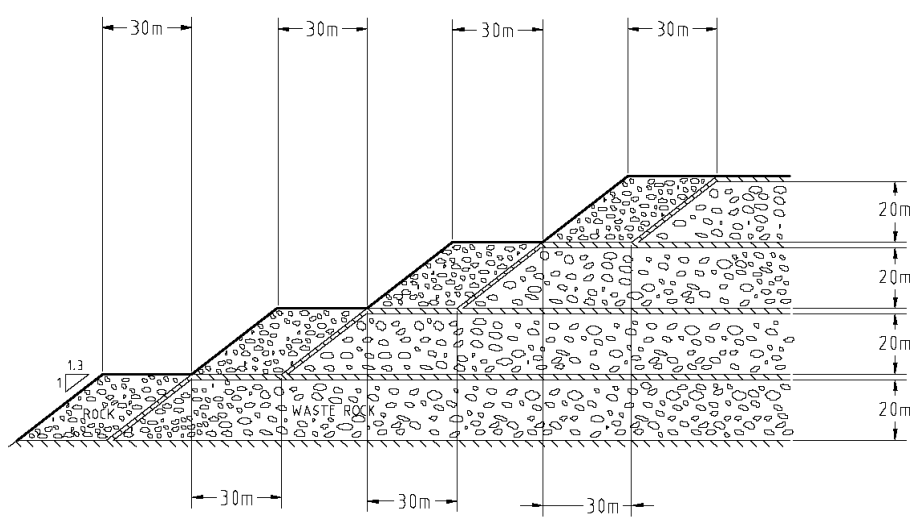

Figure 11 Type 1, $30 \mathrm{~m}$ offset

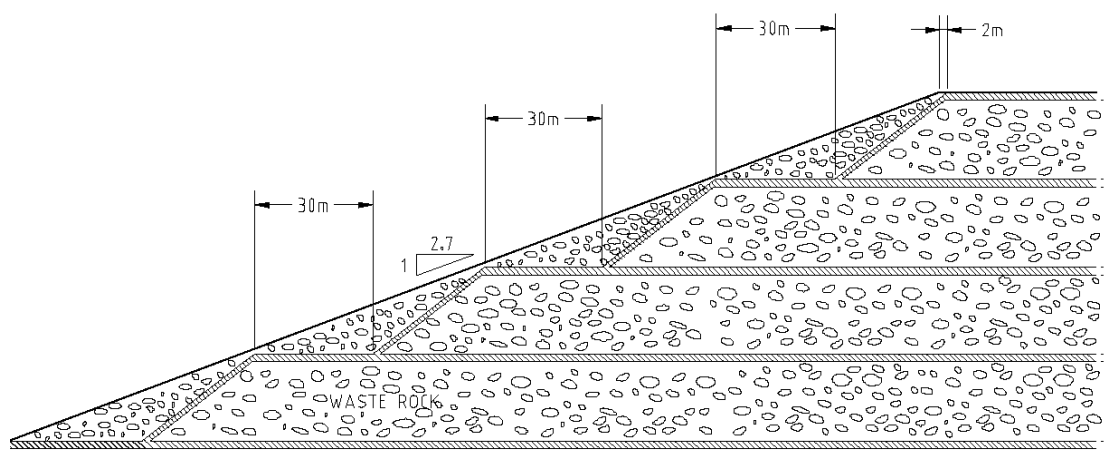

\section{Figure 12 Type 3, $30 \mathrm{~m}$ offset}

The movement of water through the soil with respect to time was modelled using the SoilCover software. SoilCover is a one dimensional model and cannot directly take slope into account. However, drainage can be modelled at various nodes to simulate losses from a drained surface. The waste rock dump has been modelled as a $2 \mathrm{~m}$ thick layer of rock on top of a layer of clay and a $10 \mathrm{~m}$ deep layer of waste rock. This is depicted in Figure 13.

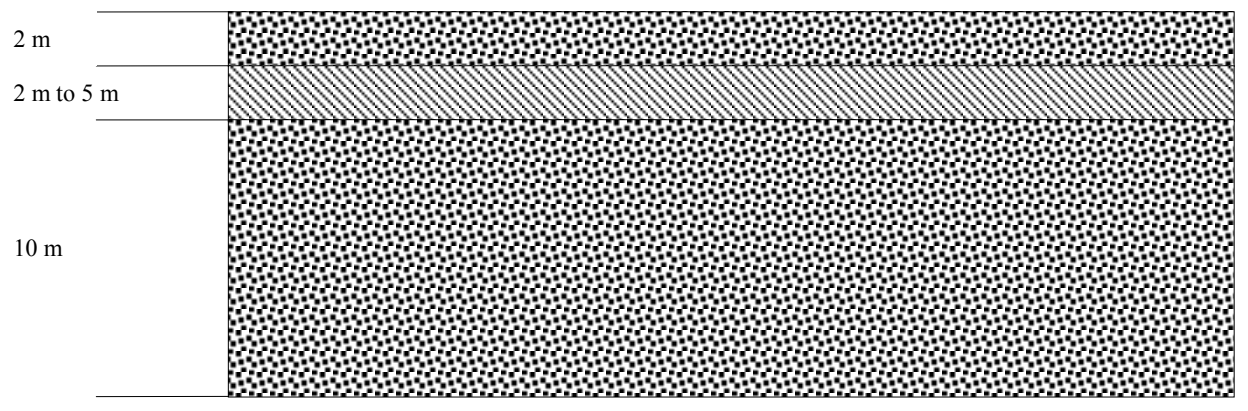

rockfill

clay

Figure 13 Modelled dump profile 
Soil properties used are shown in Table 2.

Table 2 Soil properties

\begin{tabular}{|c|c|c|c|c|c|c|}
\hline \multirow{2}{*}{ Soil } & \multirow{2}{*}{ Porosity } & Specific Gravity & \multirow{2}{*}{$\begin{array}{c}\text { Coefficient } \\
\text { of Volume } \\
\text { Change, }\end{array}$} & \multicolumn{3}{|c|}{$\begin{array}{c}\text { Soil Water Characteristic } \\
\text { Curve Constants }\end{array}$} \\
\cline { 5 - 7 } & & & (1/kPa) & A & N & M \\
\hline Rock & 0.47 & 3.225 & $1.0 \times 10^{-6}$ & 12.31 & 0.97 & 1.03 \\
\hline Clay & 0.41 & 2.650 & $2.7 \times 10^{-3}$ & 22.32 & 0.89 & 0.64 \\
\hline
\end{tabular}

Climate data for the year starting 1 July 1999 was used as representing a dry year. The total annual rainfall for that year is $1529.4 \mathrm{~mm}$, approximately $80 \%$ of the average annual rainfall for Savage River. Site Pan Evaporation data was also used.

The permeability and the thickness of the clay cover were varied to assess the affect of these on the amount of infiltration and clay saturation. Clay thickness of $2 \mathrm{~m}$ and $5 \mathrm{~m}$ has been evaluated with permeability ranging from $1 \times 10^{-5} \mathrm{~m} / \mathrm{s}$ to $1 \times 10^{-8} \mathrm{~m} / \mathrm{s}$.

Initial modelling assessed the undrained case that would correspond to a flat surface where all water infiltrating the surface layer was confined within the model. Runoff from the surface would only occur where the surface layer is fully saturated. The results of this undrained modelling are presented in Table 3 .

Table 3 Annual infiltration - undrained case

\begin{tabular}{|c|c|c|c|}
\hline Clay Permeability & Clay Thickness & Annual Infiltration & $\begin{array}{c}\text { Minimum Clay } \\
\text { Saturation }\end{array}$ \\
\hline $1 \times 10^{-5} \mathrm{~m} / \mathrm{s}$ & $2.0 \mathrm{~m}$ & $99.7 \%$ & $85 \%$ \\
\hline $1 \times 10^{-6} \mathrm{~m} / \mathrm{s}$ & $2.0 \mathrm{~m}$ & $97.8 \%$ & $95 \%$ \\
\hline $1 \times 10^{-7} \mathrm{~m} / \mathrm{s}$ & $2.0 \mathrm{~m}$ & $55.7 \%$ & $97 \%$ \\
\hline $1 \times 10^{-8} \mathrm{~m} / \mathrm{s}$ & $2.0 \mathrm{~m}$ & $8.4 \%$ & $97 \%$ \\
\hline $1 \times 10^{-5} \mathrm{~m} / \mathrm{s}$ & $5.0 \mathrm{~m}$ & $99.3 \%$ & $87 \%$ \\
\hline $1 \times 10^{-6} \mathrm{~m} / \mathrm{s}$ & $5.0 \mathrm{~m}$ & $97.8 \%$ & $95 \%$ \\
\hline $1 \times 10^{-7} \mathrm{~m} / \mathrm{s}$ & $5.0 \mathrm{~m}$ & $47.1 \%$ & $97 \%$ \\
\hline $1 \times 10^{-8} \mathrm{~m} / \mathrm{s}$ & $5.0 \mathrm{~m}$ & $8.4 \%$ & $97 \%$ \\
\hline
\end{tabular}

It can be seen that reduced permeability of the clay reduces infiltration as does increased depth of the clay to a limited extent. For clay zone permeability greater than $10^{-7} \mathrm{~m} / \mathrm{s}$ virtually all rainfall is intercepted by the rockfill and passes through the clay zone. As the permeability of the clay zone is reduced the amount of water passing through is also reduced. This would lead to build up of the level of saturation in the rockfill which would eventually lead to runoff and evaporation losses from the surface. Of particular interest in all cases is that the degree of saturation of the clay layer consistently exceeds $85 \%$ throughout the year, effectively limiting oxygen diffusion.

The performance of the cover system on the sloping face is affected by drainage of the incident rainfall through the permeable rock zone. This was modelled by applying a drainage node at the top of the clay layer. The rate of nodal drainage applied was $4 \mathrm{~mm} /$ day, equivalent to $4 \mathrm{~L} / \mathrm{day} / \mathrm{m}^{2}$ of cover, calculated by considering the potential seepage flow in the rock cover layer given the slope of the contact and the permeability of the rockfill. The drainage node prevented build up of saturated conditions in the rockfill layer. The infiltration rate and the saturation level of each of the models were significantly reduced once this drain was applied. The infiltration rates for the clay layer are included in the Table 4. 
Table 4 Infiltration rates - sloping face

\begin{tabular}{|c|c|c|c|}
\hline $\begin{array}{c}\text { Clay } \\
\text { Permeability }\end{array}$ & Clay Thickness & \% Infiltration & $\begin{array}{c}\text { Minimum Clay } \\
\text { Saturation }\end{array}$ \\
\hline $1 \times 10^{-5} \mathrm{~m} / \mathrm{s}$ & $2.0 \mathrm{~m}$ & 11.8 & $60 \%$ \\
\hline $1 \times 10^{-6} \mathrm{~m} / \mathrm{s}$ & $2.0 \mathrm{~m}$ & 7.4 & $80 \%$ \\
\hline $1 \times 10^{-7} \mathrm{~m} / \mathrm{s}$ & $2.0 \mathrm{~m}$ & 4.6 & $90 \%$ \\
\hline $1 \times 10^{-8} \mathrm{~m} / \mathrm{s}$ & $2.0 \mathrm{~m}$ & 1.2 & $95 \%$ \\
\hline $1 \times 10^{-5} \mathrm{~m} / \mathrm{s}$ & $5.0 \mathrm{~m}$ & 7.0 & $72 \%$ \\
\hline $1 \times 10^{-6} \mathrm{~m} / \mathrm{s}$ & $5.0 \mathrm{~m}$ & 6.1 & $86 \%$ \\
\hline $1 \times 10^{-7} \mathrm{~m} / \mathrm{s}$ & $5.0 \mathrm{~m}$ & 3.6 & $94 \%$ \\
\hline $1 \times 10^{-8} \mathrm{~m} / \mathrm{s}$ & $5.0 \mathrm{~m}$ & 1.3 & $95 \%$ \\
\hline
\end{tabular}

As can be seen, there is a significant reduction in infiltration in all cases but permeability still has an impact on reducing this further. The layer thickness also reduces overall infiltration, given similar material permeability. There is a significant decrease in the minimum saturation level in the clay layer but this only drops below $80 \%$ for the worst case where "clay" permeability is reduced to $1 \times 10^{-5} \mathrm{~m} / \mathrm{s}$. Even this value would be sufficient to limit oxygen diffusion based on the information in Figure 8.

The SoilCover modelling work confirmed that a sloping clay facing protected by a rockfill stabilising berm as proposed by $\mathrm{ABM}$, can effectively limit oxygen ingress to the levels required to prevent acid drainage from the waste rock dumps at Savage River mine, provided that the permeability of the "clay" cover material is not greater than $1 \times 10^{-6} \mathrm{~m} / \mathrm{s}$.

The stability analyses have shown that a stable dump should have rockfill cover at an overall slope of approximately 2.7:1 (horizontal to vertical) irrespective of the benching details of the various waste rock lifts. The rock facing can be left at the angle of repose between inter-lift benches but a saving in overall rock volumes can be achieved by flattening the outer face slope.

A field study has been set up on a section of cap on the western side of B dump to confirm the performance of the cap system. The study was set up by trenching into the "clay" layer, measuring soil properties and physical dimensions, installing instrumentation followed by completing the spreading of the A-type material. Instrumentation comprises moisture content and temperature monitoring equipment. The moisture content monitoring enables tracking of moisture content and degree of saturation to confirm the maintenance of sufficient saturation to prevent oxygen ingress. The temperature monitoring allows assessment of the extent of oxidation occurring. The installation site comprised a $15 \mathrm{~m}$ high face with the clay zone in place but the A-type final cover not yet placed. Two sites were instrumented with moisture probes and a third with temperature probes.

Figure 14 shows the study area during construction with rockfill being placed over the clay zone. Figure 15 shows excavation in progress to install instrumentation. Figure 16 shows installation of one of the Theta moisture probes. 


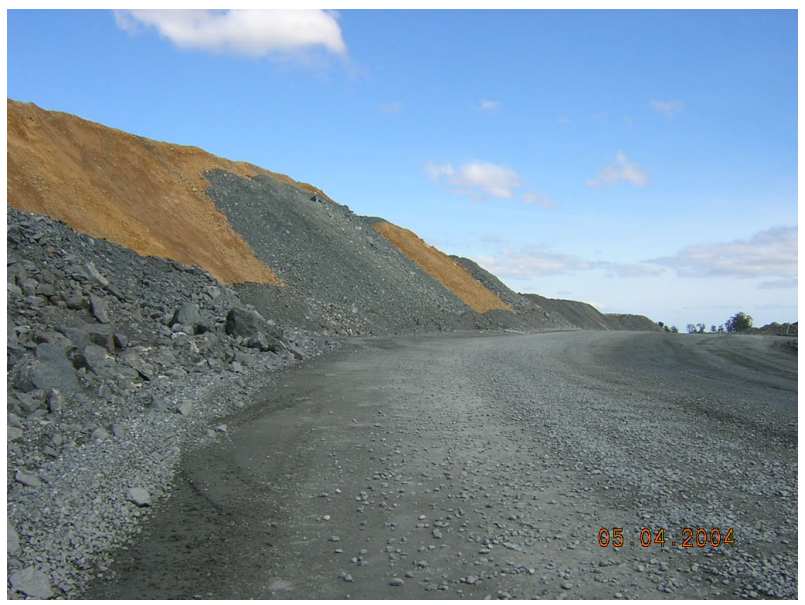

\section{Figure 14 Clay facing under construction}

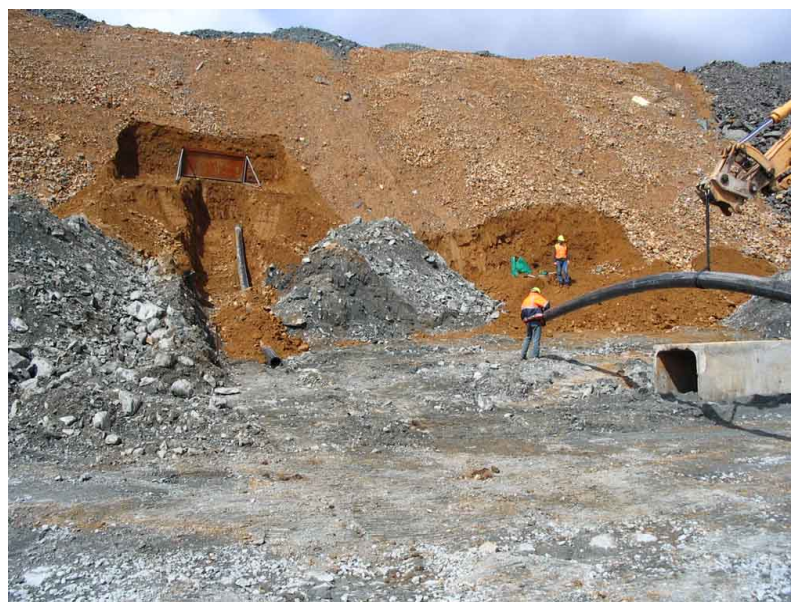

Figure 15 Setting up the clay cap test site

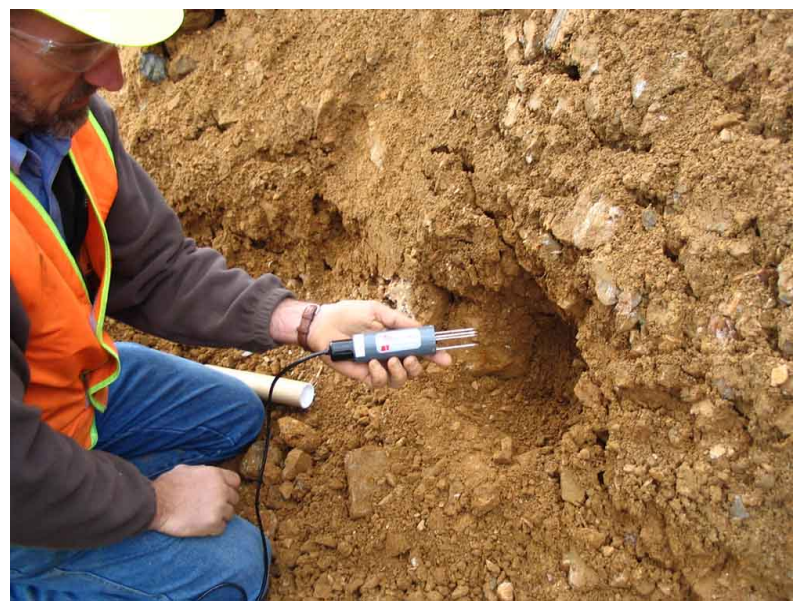

Figure 16 Installing the Theta probe moisture monitors

The cap material was found to comprise a well graded clayey gravel weathered rock and to be relatively loose at between $80 \%$ and $90 \%$ maximum dry density (standard), with initial moisture content of $10-15 \%$ representing $60 \%$ saturation in both cases. 
Saturation levels measured by the moisture probes ranged between $50 \%$ and $77 \%$ with the lower saturation levels corresponding to a higher level in the cap (i.e. closer to the surface).

Field permeability testing indicated permeability was $10^{-7} \mathrm{~m} / \mathrm{sec}$.

The instruments have been installed and are working. The saturation levels in the cover material are consistently above $50 \%$ and typically above $60 \%$ at lower levels of the cap. Based on the Acid Sulphide Generation Rate chart shown in Figure 7, these levels would reduce ASGR by an excess of $95 \%$, confirming the effectiveness of the cover system. The Theta probes appear to be presenting realistic results for volumetric moisture content. Monitoring of volumetric moisture levels will be used to confirm that the cap layer maintains adequate saturation levels over time.

\section{Conclusions}

It is concluded that relatively simple construction techniques can be used to construct major waste rock dump structures that are environmentally stable and limit the risk of acid rock drainage impacts. However a high level of commitment and field control is required by the construction personnel. In this case the flowthrough dump was instrumental in allowing economically viable mining and also the best practice environmental management of potentially acid producing waste rock. Similarly a practical and effective capping system has been developed that suits the mine's earthmoving operations. These techniques will help ensure that the current mining operations do not leave legacies of degraded river systems as has been the case in the past.

\section{Acknowledgement}

The assistance of Australian Bulk Minerals in granting permission for the publication of this paper is acknowledged.

\section{References}

Brett, D. and Hutchison, B.J. (2003) Design and Performance of a "Flow - Through" Spillway at Broderick Creek Waste Rock Dump -Savage River mine, Australian Journal of Water Resources, Vol. 6, No. 2.

Brett, D. (2006) Strategic Planning For ARD Remediation, 7th ICARD, March 26-30, St Louis MO. Published by ASMR, 3134 Montavesta Rd., Lexington, KY 40502.

Hutchison, B.J. (2006) SRRP - B Dump Water Shedding Cover-Construction Report, October 2006.

Rumble, C. (2000) Presentation to Australian Bulk Minerals at Savage River Mine, unpublished. 